\title{
The Selectivity of the Human Placenta in the Transfer of Plasma Proteins from Mother to Fetus*
}

\author{
David Gitlin, Jesús Kumate, Juan Urrusti, and Carlos Morales \\ (From the Hospital Infantil de México, the Hospital de Gineco-Obstetricia, Centro Médico \\ Nacional del I.M.S.S., México, D. F., the Children's Hospital Medical Center, \\ Boston, Mass., and the Children's Hospital, Pittsburgh, Pa.)
}

The passage of plasma proteins from mother to fetus in humans appears to be highly selective. Although a number of antibodies such as those against diphtheria $(1,2)$ and tetanus toxins $(3)$, typhoid $\mathrm{H}$ antigen (4), and poliomyelitis virus (5) readily cross from the maternal plasma to that of the fetus, other antibodies such as those against typhoid $\mathrm{O}$ antigen do not (4). This apparent variability in the maternofetal transfer of plasma antibodies has been shown to depend upon the class of plasma proteins to which the specific antibodies belong $(6,7)$ : antibodies that are $7 \mathrm{~S}$ $\gamma_{2}$-globulins pass from mother to fetus, but those antibodies that are $19 \mathrm{~S} \gamma_{1}$-globulins do so much less effectively or not at all. That the maternofetal barrier may also be relatively impermeable to $\gamma_{1 \mathbf{A}^{-}}$ globulin antibodies and to ceruloplasmin and haptoglobin as well is suggested by the observation that the concentrations of these proteins in the plasma of the fetus at term are less than $15 \%$ of those in the maternal plasma $(8-10)$. Although $19 \mathrm{~S} \gamma_{1^{-}}$ globulin is much larger in molecular weight than $7 \mathrm{~S} \gamma_{2}$-globulin, ceruloplasmin and haptoglobin have molecular weights that are similar to or smaller than that of $7 \mathrm{~S} \gamma_{2}$-globulin. The selective transfer of $7 \mathrm{~S} \gamma_{2}$-globulin across the maternofetal barrier, therefore, may not be determined solely by molecular size.

The nature of this selective maternofetal transfer of $7 \mathrm{~S} \gamma_{2}$-globulin has been studied by Brambell and his colleagues in rabbits $(11,12)$. The $7 \mathrm{~S} \gamma_{2}$-globulin molecule can be hydrolyzed by

* Submitted for publication February 24, 1964 ; accepted June 22, 1964.

Presented in part before the American Pediatric Society, Atlantic City, N. J., May 4, 1963. Supported by grants from the Rockefeller Foundation, the National Institutes of Health, U. S. Public Health Service (AM00251 and HD-00652), and the Ronnie Miller Fund of Children's Hospital of Pittsburgh. papain into three major polypeptide fragments nearly equal in molecular size: two of these fragments each contain a single antibody site, whereas the third fragment has no antibody activity (13). By labeling such fragments obtained from rabbit $\gamma_{2}$-globulin and injecting them into the pregnant doe, the amount found in the fetus 24 hours later could be determined; the data suggested that the transmission of $7 \mathrm{~S} \gamma_{2}$-globulin to the fetus depends upon the nonantibody portion of the molecule (12).

In this study the selectivity of the transfer of $7 \mathrm{~S} \gamma_{2}$-globulin was reinvestigated in the pregnant woman by using several labeled human proteins of different molecular weights and fragments of $7 \mathrm{~S} \gamma_{2}$-globulin obtained by papain hydrolysis.

\section{Methods}

Plan of study. Normal women in their last month of an uncomplicated pregnancy were given $100 \mathrm{mg}$ of stable $\mathrm{KI}$ orally per day. After administration of the KI was begun, the women were given a single intravenous injection of a specific human plasma protein labeled with $\mathrm{I}^{131}$; the injection was given at a time varying from a few minutes to 4 weeks before delivery. Between the time of injection and the time of confinement for the delivery, the women were ambulatory and attended the outpatient department of the Hospital de Gineco-Obstetricia, Centro Médico Nacional del I.M.S.S., for routine prenatal care. The amount of labeled protein given each woman was $2 \mathrm{mg}$ or less, and the amount of radioactivity in each injection varied from $0.15 \mu \mathrm{c}$ of $\mathrm{I}^{131}$ per $\mathrm{kg}$ of body weight when radioiodinated $7 \mathrm{~S} \boldsymbol{\gamma}_{2}$-globulin was injected to $0.4 \mu \mathrm{c}$ of $\mathrm{I}^{131}$ per $\mathrm{kg}$ of body weight when radioiodinated acid glycoprotein was studied. Measurements over the thyroidal area of several of the newborn infants selected at random in this study indicated a level of radioactivity virtually identical to that over a similar area of the thigh of the same infant without evidence of localized concentrations, indicating effective inhibition of thyroidal uptake of radioiodide by the stable iodide given the mother. The maximal amount of radiation received by the vascular system and 
its contents, which were the tissues of maximal concentration of the radioisotope, was less than 100 millirads for the mother and less than 30 millirads for the fetus.

The amount of radioactivity in the maternal plasma 10 minutes after injection of the labeled protein at various intervals before delivery and during the delivery of the infant was determined as well as that in the infant's cord plasma at birth. When possible, samples of amniotic fluid were obtained per vagina when the mother's membranes ruptured; the amounts of radioactivity in samples of this fluid were determined also.

Proteins studied. The preparations of acid glycoprotein, albumin, transferrin, $7 \mathrm{~S} \gamma_{2}$-globulins, and fibrinogen used in this study were obtained from the pooled plasma of normal adults by using the low temperature ethanol-water fractionation methods of Cohn and his colleagues.

1) Three times crystallized acid glycoprotein, or orosomucoid, was used. ${ }^{1}$ The protein has a molecular weight of 44,000 (14).

2) The plasma albumin used was preparation decanol 10 , a twice crystallized albumin that has been characterized physicochemically and immunochemically in earlier reports $(15,16)$.

3) The four times crystallized transferrin, or iron-binding globulin, ${ }^{2}$ used was electrophoretically homogeneous, although traces of albumin and $\gamma_{2}$-globulin, less than $1 \%$ of each, were found by the quantitative immunochemical precipitation method. Transferrin has a molecular weight of approximately $90,000(17,18)$.

4) The $7 \mathrm{~S} \gamma_{2}$-globulin preparation used had a sedimentation coefficient, $S_{20, \mathrm{w}}$, of $6.8 \mathrm{~S}$ in a $1 \%$ solution, and it contained over $98 \% \gamma_{2}$-globulin as determined electrophoretically on paper and by moving boundary. With the quantitative precipitin method, the preparation was found to contain approximately $1 \%$ albumin.

5) The starting material for the purified fibrinogen used in this study was irradiated, Seitz-filtered Fraction I of Cohn as prepared by the method of Blombäck and Blombäck (19); the fibrinogen was isolated from this fraction by Dr. Edward Hershgold using the method of Morrison, Edsall, and Miller (20). Approximately 95\% of the protein in the final preparation of fibrinogen was readily clotted with thrombin, and the clottability of the preparation was not affected significantly by radioiodination.

6) Macroglobulins were isolated from the plasma of a single adult donor by Dr. Philip Fireman and Dr. Fred Rosen: $25 \mathrm{ml}$ of fresh plasma was passed through a $2.5-\mathrm{cm}$ by $150-\mathrm{cm}$ column of Sephadex G-200 ${ }^{3}$ equilibrated with $0.1 \mathrm{M} \mathrm{NaCl}$; the first portion of the first protein peak in the effluent was concentrated by negative pressure dialysis and centrifuged in a sucrose gradient (21), $10 \%$ at the top of the tube to $40 \%$ at the bot-

1 Kindly supplied by Dr. Karl Schmid of Boston University.

2 Obtained from Dr. J. L. Oncley of the University of Michigan.

3 Pharmacia, Uppsala, Sweden. tom, at 105,000 times $g$ in a swinging bucket in a Spinco model L ultracentrifuge for approximately 18 hours. The protein in the bottom $1 \mathrm{~cm}$ of the tube was collected with the aid of a tube slicer and was used, after dialysis against $0.15 \mathrm{M} \mathrm{NaCl}$, without further purification. The proteins in this preparation had a sedimentation velocity, $S_{20, \mathrm{w}}$, of approximately $19 \mathrm{~S}$, and immunoelectrophoresis revealed that the proteins present were $\alpha_{2}$-macroglobulin and $\gamma_{1}$-macroglobulin; after radioiodination and separation of the radioactive proteins by paper electrophoresis, approximately $55 \%$ of the total radioactivity was associated with $\alpha_{2}$-macroglobulin and $45 \%$ with $\gamma_{1}$-macroglobulin.

7) Polypeptide fragments were obtained from $7 \mathrm{~S} \gamma_{2^{-}}$ globulin by hydrolysis with papain (13) at $\mathrm{pH} 7.0$ in an enzyme to protein ratio of $1: 1,000$ by weight as described elsewhere (22). These fragments were each approximately 50,000 in molecular weight with a modification of the sedimentation equilibrium method of McFariane and Kekwick (23), and three fragments were obtained per hydrolyzed $7 \mathrm{~S} \gamma_{2}$-globulin molecule. Two of the fragments each contained one of the two antibody sites of the original $7 \mathrm{~S} \gamma_{2}$-globulin antibody molecules; these were the $\mathrm{S}$ fragments (24). The remaining large fragment had little or no detectable antibody activity and was readily crystallized (23) ; this fragment was the $\mathrm{F}$ fragment (24). Isolation of these fragments from the papain hydrolysate of $7 \mathrm{~S} \gamma_{2}$-globulin was performed by using columns of DEAE cellulose and Sephadex G-100 as described elsewhere (22). The final preparation of $\mathrm{F}$ fragment contained less than $0.1 \%$ of $\mathrm{S}$ fragments as determined immunochemically. The preparation of $\mathrm{S}$ fragments contained several immunochemically related components, all of which were immunochemically different from the $\mathrm{F}$ fragment; if any undegraded $7 \mathrm{~S} \gamma_{2}$-globulin was present in this preparation, its concentration was less than $0.1 \%$ by weight as determined immunochemically.

8) Low molecular weight $\gamma$-globulins were isolated as described elsewhere (25) from the urine of normal adult males whose blood had been transfused into sick children on several occasions without clinical manifestations of hepatitis in the recipients. These proteins, which are termed $\gamma_{\mathrm{u}}$-globulins in this report, were heterodisperse in the ultracentrifuge, having an average sedimentation velocity of $S_{20, w}=1.5$, with a range from less than $1 \mathrm{~S}$ and a molecular weight of 12,500 to $3 \mathrm{~S}$ with a molecular weight of $30,000(25)$. The $\gamma_{u}$-globulins were immunochemically related to the $\mathrm{S}$ fragments obtained from $7 \mathrm{~S}$ $\gamma_{2}$-globulins: rabbit antisera prepared against the $\gamma_{u^{-}}$ globulins cross-reacted with $\mathrm{S}$ fragments, and antisera against $S$ fragments cross-reacted with $\gamma_{u}$-globulins. Like the $S$ fragments, the $\gamma_{u}$-globulins possessed antibody activity (25) and were immunochemically distinct from the $\mathrm{F}$ fragment of $7 \mathrm{~S} \gamma_{2}$-globulin.

Radioiodination. The proteins were labeled with $\mathrm{I}^{131}$ by a modification of the nitrous acid method of Pressman and Eisen (26). Briefly, carrier-free $I^{131}$ was obtained as iodide in bisulfite; $2 \mu$ moles of stable $\mathrm{KI}_{3}$ was added to the radioiodide for each micromole of protein 
to be iodinated and then oxidized to $I_{2}$ with nitrous acid. After bringing the radioiodine solution to $\mathrm{pH} \mathrm{7,} \mathrm{it} \mathrm{was}$ then added to the protein, which was dissolved in bicarbonate buffer at $\mathrm{pH}$ 9.3. The efficiency of iodination by this method was approximately 15 to $20 \%$, and the iodinated protein contained an average of approximately 0.5 atoms of iodine per molecule of protein. Nonprotein radioactivity was removed from the labeled protein solutions by passage through 1 - by $5-\mathrm{cm}$ columns of Dowex-2 resin followed by dialysis against several changes of $0.15 \mathrm{M} \mathrm{NaCl}$ for 24 hours. Sterilization of the final solutions was accomplished by pressure filtration through an ultrafine sintered glass filter, and bacterial sterility was confirmed by culture on blood agar and in infusion broths.

Not more than $2 \%$ of the total radioactivity of the final preparation of each of the labeled proteins, with the exception of the labeled $\gamma_{\mathrm{u}}$-globulins, remained unprecipitated in $10 \%$ trichloroacetic acid (TCA). Since a large proportion, approximately $20 \%$, of the unlabeled $\gamma_{u}$ globulin was not precipitable in $10 \%$ TCA, the amount of protein-bound radioactivity in the radioiodinated $\gamma_{\mathrm{u}}$-globulin preparation could not be determined by this method; however, less than $2 \%$ of the total radioactivity could be removed from the solution of labeled urine $\gamma$-globulin by further dialysis against $0.15 \mathrm{M} \mathrm{NaCl}$ for 72 hours.

A single preparation of each of the radioiodinated proteins was used in this study with the exception of radioiodinated $7 \mathrm{~S} \gamma_{2}$-globulin. In the case of the latter protein, two preparations of the labeled protein were used,

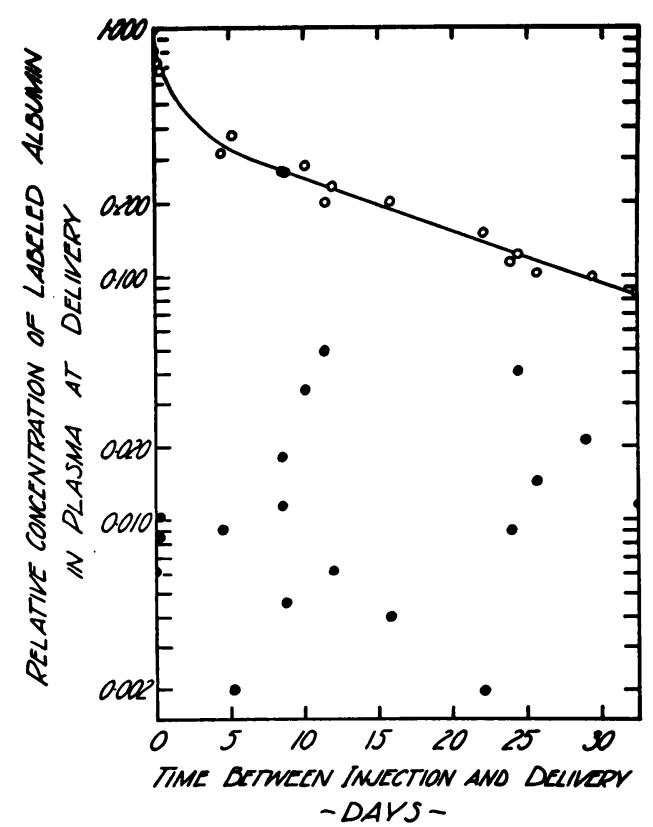

Fig. 1. Disappearance of Radiolodinated Albumin FROM THE PLASMA OF PREGNANT WOMEN (HOLLOW CIRCLES) AND THE CONCENTRATION OF THIS PROTEIN IN CORD PLASMA OF THEIR INFANTS (SOLID CIRCLES) RELAtive to THE MATERnal PLASMa CONCENTRATION 10 MiNUTES AFTER INJECTION.

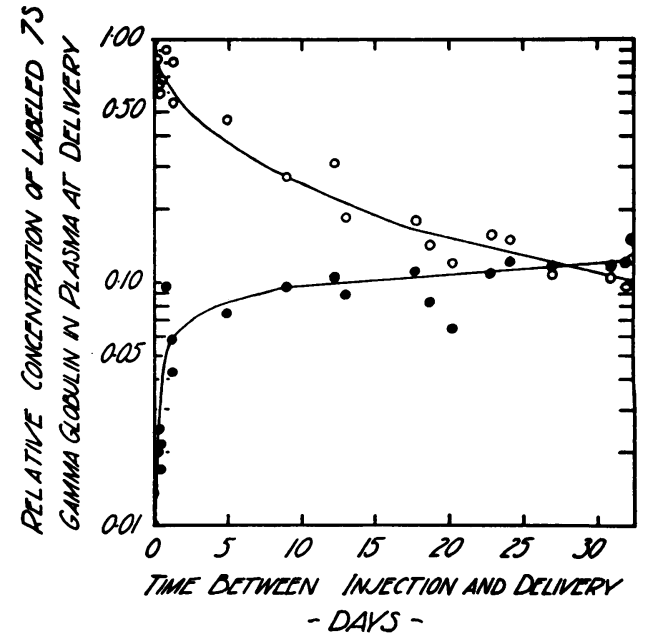

Fig. 2. Disappearance of Radioiodinated $7 \mathrm{~S} \boldsymbol{\gamma}_{2}$-GlobULIN FROM THE PLASMA OF PREGNANT WOMEN (HOLLOW CiRCles) AND THE CONCENTRATION OF THIS PROTEIN IN CORD PLASMA OF THEIR INFANTS (SOLID CIRCLES) RELATIVE TO THE MATERNAL PLASMA CONCENTRATION 10 MinUteS AFTER INJECTION.

13 women being studied with one and 10 women with the other.

Estimation of radioactivity. Samples of plasma and amniotic fluid were placed in 4-ml vials, and the radioactivity in each sample was estimated with a 2 -inch welltype $\mathrm{NaI}$ crystal; counting efficiency for $\mathrm{I}^{131}$ was approximately $50 \%$, and counting standards were used to avoid problems incident to radioactive decay, changes in the counting efficiency of the system, and differences in the geometry of the samples. Nonprotein radioactivity was determined in samples of plasma and amniotic fluid by precipitating the proteins with an equal volume of $10 \%$ TCA, centrifuging, and estimating the radioactivity in a sample of the supernatant fluid.

In a few instances, zonal electrophoresis in starch (27), filtration through Sephadex (28), and precipitation with rabbit antiserum were used to determine the nature of the radioactivity in the sera of women given labeled $S$ fragment and in the corresponding cord sera. The starch blocks used for electrophoresis measured 4 by $30 \mathrm{~cm}$, and electrophoresis was performed in barbital buffer, $\mathrm{pH} \mathrm{8.6,} \mathrm{of} \mathrm{ionic} \mathrm{strength} 0.1$ at $15 \mathrm{v}$ per $\mathrm{cm}$ for 18 hours at $4^{\circ} \mathrm{C}$. The blocks were then cut into segments $1 \mathrm{~cm}$ wide and the proteins eluted with $0.15 \mathrm{M} \mathrm{NaCl}$. The eluates were assayed for radioactivity and the optical densities of the eluates determined in a Beckman spectrophotometer at a wave length of $280 \mathrm{~m} \mu$. Two different columns of Sephadex, each $2.5 \mathrm{~cm}$ wide, were used for each sample of serum to be studied; elution in each was with $0.1 \mathrm{M} \mathrm{NaCl}$, and the eluates were collected in $5-\mathrm{ml}$ volumes. The serum was first passed through a column consisting of a layer of G-25 over a layer of G-50, each layer being $18 \mathrm{~cm}$ high; the optical densities of the eluates were determined at a wave length of 280 
$\mathrm{m} \mu$ and the eluates assayed for total and TCA-precipitable radioactivity. The proteins excluded by this column were then pooled, and a $10-\mathrm{ml}$ sample was passed through the second column of Sephadex, which consisted of layers of G-75, G-100, and G-200 from top to bottom, each layer being approximately $13 \mathrm{~cm}$ high. Again optical densities and total and TCA-precipitable radioactivity of the eluates were determined. The concentrations of albumin and $7 \mathrm{~S} \gamma_{2}$-globulin in the latter eluates were also estimated.

The rabbit antiserum used for precipitating $S$ fragments was one that was prepared against $7 \mathrm{~S} \gamma_{2}$-globulin. The antiserum readily precipitated over $95 \%$ of the labeled $\mathrm{S}$ fragment preparation used, whether the latter was mixed with carrier $\mathrm{S}$ fragments or $7 \mathrm{~S} \gamma_{2}$-globulin; it did not precipitate $F$ fragment.

Immunochemical estimation of plasma protein concentrations. The concentrations of albumin, transferrin, $7 \mathrm{~S} \gamma_{2}$-globulin, and fibrinogen in maternal and cord sera (Table I) were estimated immunochemically by a unidimensional agar diffusion method (29) as described

TABLE I

Concentrations of specific proteins in maternal and cord plasma and in amniotic fluid

\begin{tabular}{lccc}
\hline \multirow{2}{*}{\multicolumn{1}{c}{ Protein }} & \multicolumn{2}{c}{ Plasma } & \\
\cline { 2 - 3 } & Mother & Newborn & $\begin{array}{c}\text { Amniotic } \\
\text { fluid }\end{array}$ \\
\hline & $g / 100 \mathrm{ml}$ & $\mathrm{g} / 100 \mathrm{ml}$ & $\mathrm{g} / 100 \mathrm{ml}$ \\
Albumin & 3.23 & 3.45 & 0.200 \\
Transferrin & 0.401 & 0.179 & 0.006 \\
7 S $\gamma_{2}$-globulin & 1.75 & 1.56 & 0.189 \\
Fibrinogen & 0.538 & 0.392 & 0 \\
\hline
\end{tabular}

elsewhere (30). The same method was used to estimate the concentrations of albumin and $7 \mathrm{~S} \gamma_{2}$-globulin in the eluates obtained from the Sephadex columns. Briefly, the specific antiserum was incorporated into $0.5 \%$ agar in borate buffer of $\mathrm{pH} 8.6$ and placed in glass tubes, $10 \mathrm{~cm}$ long with an internal diameter of $4 \mathrm{~mm}$, so that about half of the tube was filled; the top half of the tube was filled with the fluid to be studied. After 24 hours, the distance between the agar-fluid interface and the precipitin band that formed in the agar phase was measured and the concentration of specific protein determined from a standard curve that was obtained with duplicate tubes and known concentrations of the given protein. Albumin and $7 \mathrm{~S} \gamma_{2}$-globulin were estimated with horse antisera; transferrin and fibrinogen were determined with rabbit antisera.

\section{Results}

I. The disappearance of radioiodinated proteins from the plasma. The disappearance of radioiodinated proteins from the plasma of pregnant women during the last month of gestation is shown in Figures 1 to 4 : the relative concentration of labeled protein remaining in the plasma at the time

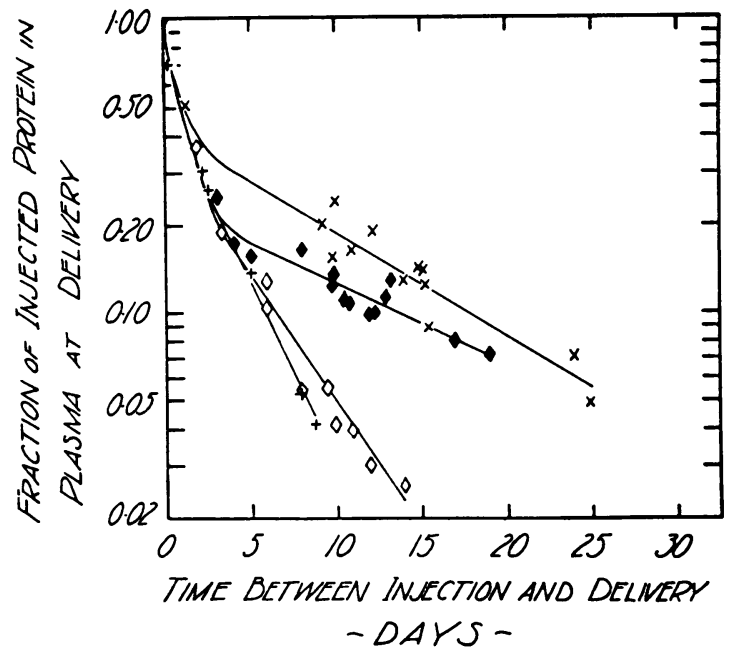

Fig. 3. Plasma disappearance of Radioiodinated 19 S MACroglobllin (X), traNSFERriN (solid DIAMONDS), ACID GLYCOPROTEIN (HOLLOW DIAMONDS), AND FIBRINOGEN (CROSSES) IN PREGNANT WOMEN.

of delivery is given as $C_{m} / C_{o}$, where $C_{o}$ is the concentration of protein-bound radioactivity in the plasma of a given woman 10 minutes after injection, and $C_{m}$ is that in the plasma of the same woman at the time of the delivery of the infant. The logarithm of $\mathrm{C}_{\mathrm{m}} / \mathrm{C}_{\mathrm{o}}$ obtained for each mother injected with a given protein was plotted against the time that had elapsed between the injection of

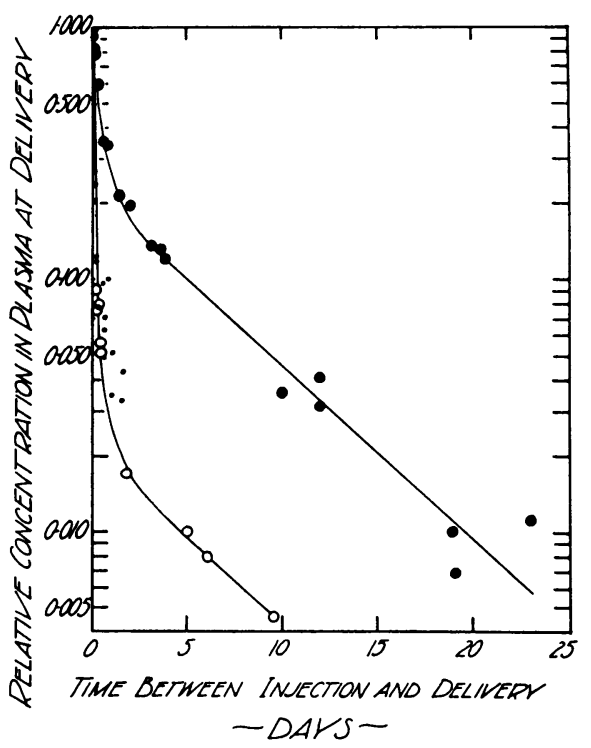

Fig. 4. Plasma disappearance of radioiodinated F FRAGMENT (SOLID CIRCLES), S FRAGMENTS (hOLLOW CIRCLES), AND LOW MOLECULAR WEIGHT URINE $\gamma$-GLOBULIN (DOTS) IN PREGNANT WOMEN. 
TABLE II

Half-lives of radioiodinated proteins in the pregnant women at term

\begin{tabular}{|c|c|c|c|}
\hline Protein & $\begin{array}{l}\text { Number } \\
\text { of } \\
\text { mothers } \\
\text { studied }\end{array}$ & $\begin{array}{l}\text { Amount } \\
\text { of radio- } \\
\text { activity } \\
\text { injected }\end{array}$ & $\begin{array}{l}\text { Average } \\
\text { half-life } \\
\text { of protein } \\
\text { in mother }\end{array}$ \\
\hline & & $\mu c / k g$ & days \\
\hline $\begin{array}{l}\text { Acid glycoprotein } \\
\text { Albumin } \\
\text { Transferrin } \\
7 \mathrm{~S} \gamma^{2-g l o b u l i n} \\
\text { Fibrinogen } \\
19 \mathrm{~S} \text { macroglobulin } \\
\text { F fragments } \\
\text { S fragments }\end{array}$ & $\begin{array}{l}14 \\
18 \\
16 \\
23 \\
11 \\
13 \\
13 \\
10\end{array}$ & $\begin{array}{l}0.4 \\
0.2 \\
0.3 \\
0.15 \\
0.2 \\
0.4 \\
0.2 \\
0.2\end{array}$ & $\begin{array}{r}3.8 \\
14.5 \\
12 \\
20.5 \\
2.5 \\
8.0 \\
4.0 \\
0.3\end{array}$ \\
\hline$\gamma_{\mathrm{u}}-$ Globulins* & 15 & 0.2 & $\begin{array}{c}(10 \%=4.0) \\
0.4\end{array}$ \\
\hline
\end{tabular}

* Low molecular weight urine $\gamma$-globulins.

the protein and the delivery. Since each determination of $\mathrm{C}_{\mathrm{m}} / \mathrm{C}_{0}$ represents the plasma disappearance of a labeled protein in but one person, the average plasma disappearance curve thus obtained for a given protein represents a composite of the determinations of $\mathrm{C}_{\mathrm{m}} / \mathrm{C}_{\mathrm{o}}$ in 10 to 23 different women. The average half-times of turnover or half-lives, $t_{2}$, of the proteins studied were estimated from these plasma disappearance curves by simple graphic analysis; the half-lives thus determined are listed in Table II.

The plasma disappearance of the labeled $\mathrm{S}$ fragment preparation (Figure 4) beginning 3 to 4 days after injection reached a relatively constant fractional rate representing a half-life of 4 days. If we assume a body distribution of the $\mathrm{S}$ fragments similar to that obtained for the other proteins and the $\mathrm{F}$ fragment, the component with a half-life of 4 days would represent about $10 \%$ of the total $\mathrm{S}$ fragment preparation; graphic analysis of the disappearance curve then yielded a $t_{\frac{1}{2}}$ of plasma disappearance of 0.3 days for the remaining polypeptides in the $\mathrm{S}$ fragment preparation during the period from approximately 8 hours to 3 days after injection. In accord with these differences in the $t_{\frac{1}{2}}$ of disappearance of different fractions of the labeled $\mathrm{S}$ fragments, the nature of the protein-bound radioactivity present in the maternal serum appeared to change with time after injection. The protein-bound radioactivity present in the preparation of labeled $\mathrm{S}$ fragments mixed in vitro with normal serum and that present in maternal serum obtained 10 minutes after injection of the labeled $\mathrm{S}$ fragments had similar properties by starch block electrophoresis and
Sephadex filtration: the protein-bound radioactivity had the mobility of a slow $\gamma_{2}$-globulin on starch electrophoresis (Figure 5A); it was excluded by Sephadex G-50, and it appeared with or just after albumin upon elution from the mixed column of Sephadex G-75, G-100, and G-200 (Figure 5E). In maternal serum obtained 8 to 12 hours after injection, the mobility of the protein-bound radioactivity appeared to be slightly faster than that present 10 minutes after injection (Figure 5B); the protein-bound radioactivity was excluded by Sephadex G-50, and it appeared with or somewhat before albumin, but after $7 \mathrm{~S} \gamma_{2^{-}}$ globulin, upon elution from mixed columns of Sephadex G-75, G-100, and G-200 (Figure 5C). Of the total radioactivity present in the maternal serum, variable amounts were included in Sephadex G-25 or G-50; the radioactivity in these fractions was not precipitable with TCA even in the presence of added carrier serum.

The maternal plasma disappearance of labeled $\gamma_{\mathrm{u}}$-globulins was followed for only 44 hours, but during the time from approximately 8 hours after the injection until the end of the observation period, the $t_{\frac{1}{2}}$ of disappearance from the maternal plasma was 0.4 days; this $t_{t}$ is similar to that obtained for the major fraction of labeled $\mathrm{S}$ fragments during the same interval after injection.

In some instances, the plasma of the infant at birth contained sufficient amounts of radioactivity to permit following the plasma disappearance of the labeled protein in the child over a period of 4 to 10 days: the disappearance of radioiodinated $7 \mathrm{~S} \gamma_{2}$-globulin transferred from mother to fetus was studied in 8 newborns, and the disappearance of radioiodinated albumin transferred from mother to fetus was followed in 6 newborns. For both $7 \mathrm{~S}$ $\gamma_{2}$-globulin and albumin, the fractional rate of disappearance of the labeled protein from the plasma in most of the infants studied was almost constant from birth, even if the infant was born as soon as 24 hours after injection of the protein into the mother, indicating that the rate of diffusion of these proteins from the infant's plasma into the infant's extravascular fluids was greater than the rate of transfer of the proteins from mother to fetus. The estimated half-lives of these proteins varied widely in the newborns that could be followed, from 7 days to 25 days for transferred 
labeled $7 \mathrm{~S} \gamma_{2}$-globulin and from 5 days to 15 days for transferred labeled albumin.

II. The appearance of radioiodinated proteins in fetal plasma. The concentration of labeled albumin and $7 \mathrm{~S} \gamma_{2}$-globulin found in the infant at birth at various intervals after the injection of these proteins into the maternal circulation is shown in Figures 1 and 2. The infant's plasma concentration of labeled albumin was extremely variable: some infants had but 0.2 to $0.4 \%$ of the initial maternal plasma concentration, whereas other infants had plasma concentrations of 1 to
$5 \%$ of the initial maternal concentration in a similar time interval. On the other hand, the infant's plasma concentration of labeled $7 \mathrm{~S} \gamma_{2}$-globulin at birth increased quite uniformly with increasing time after injection of the labeled protein into the mother, rising to levels above $10 \%$ of the initial maternal plasma concentration after 10 days.

Since the infant's plasma concentration of labeled protein is dependent in part upon the maternal plasma concentration of labeled protein, and since the maternal concentration of $7 \mathrm{~S} \gamma_{2}$-globulin decreased more slowly than that of labeled
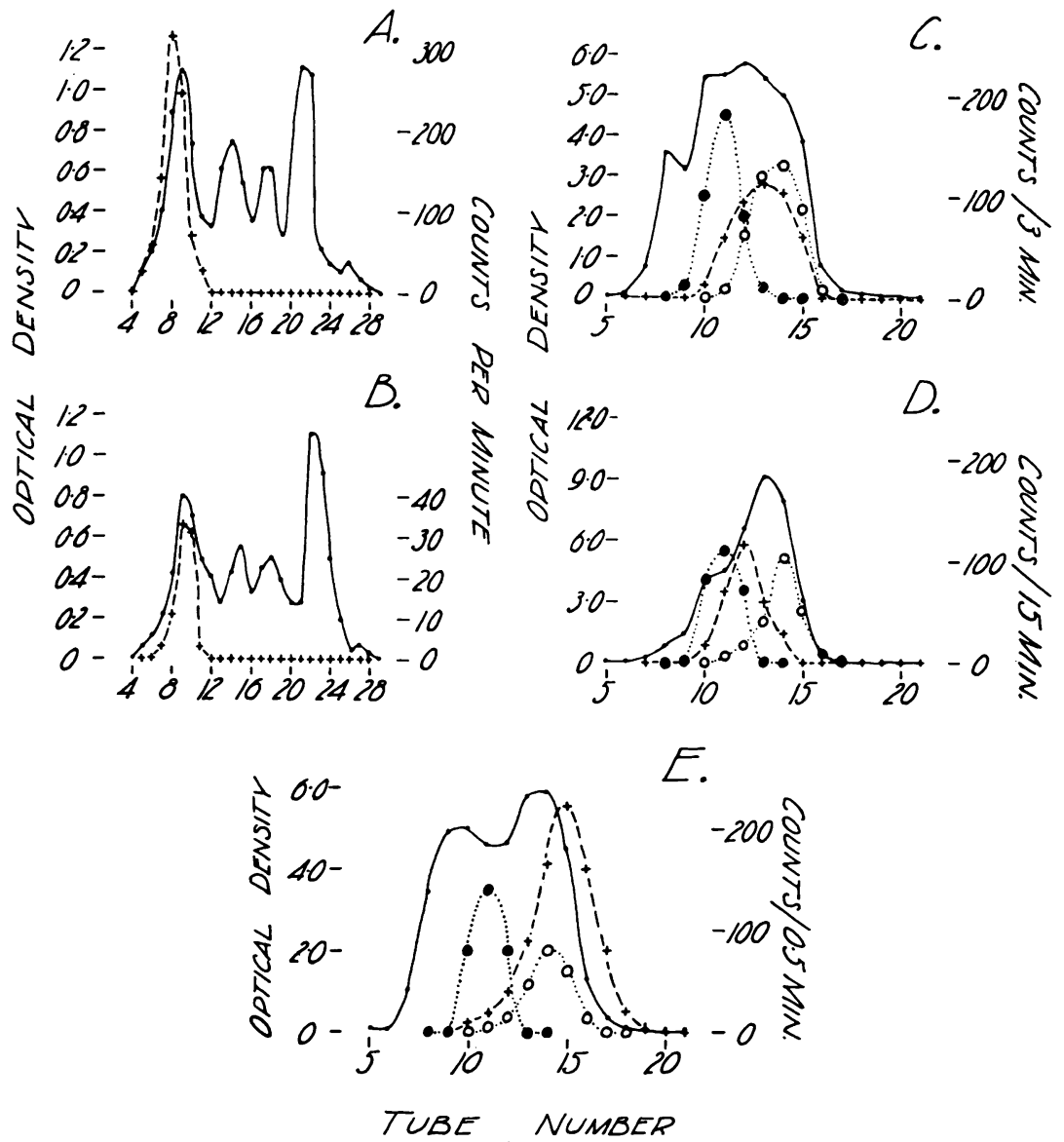

Fig. 5. A and B : Electrophoresis of maternal SERA ON STARCh block; 1-CM SEGMENTS (ABSCISSA). A : 10 minutes after injection of $S$ fragments. B: 8 hours after injection of $\mathrm{S}$ fragments. C THROUGH $\mathrm{E}$ : 5-ML vOLUMES ELUTED FROM mixed columns of Sephadex G-75, G-100, and G-200. C: Maternal serum obtained 12 hours after injection of $\mathrm{S}$ fragments. D : Cord serum obtained 12 hours after injection of $\mathrm{S}$ fragments. $\mathrm{E}$ : Serum from a normal adult to which was added labeled $\mathrm{S}$ fragments in vitro. Symbols: solid line = optical density; crosses $=$ radioactivity; hollow circles $=$ albumin concentrations (given along ordinate to right of figure in terms of $\mathrm{mg}$ per $100 \mathrm{ml} \times 10^{-1}$ ); solid circles $=7 \mathrm{~S} \gamma_{2}$-globulin concentrations (given along ordinate to right of figure in terms of $\mathrm{mg}$ per 100 $\mathrm{ml})$. The scale for radioactivity changes in $\mathrm{C}$ through $\mathrm{E}$. 


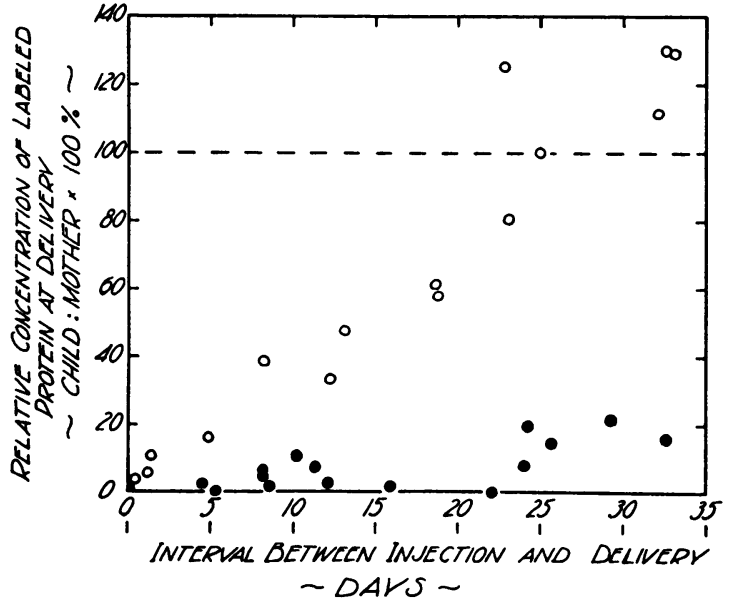

Fig. 6. Concentration of Radiolodinated $7 \mathrm{~S} \boldsymbol{\gamma}_{2-}$ GLOBULIN (HOLLOW CIRCLES) AND ALbUMiN (SOLID CIRCLES) IN CORD PLASMA OF THE INFANT AT BIRTH RELATIVE TO THE CONCENTRATIONS OF THESE PROTEINS IN THE MATERNAL PLASMA AT DELIVERY.

albumin, the concentration of labeled protein in the infant's plasma at delivery, $C_{i}$, was expressed in terms of the maternal plasma concentration at that time, or $\mathrm{C}_{\mathrm{l}} / \mathrm{C}_{\mathrm{m}}$; the more rapid increase in the infant's plasma concentration of $7 \mathrm{~S} \gamma_{2}$-globulin compared to the increase found for labeled albumin is readily apparent (Figure 6). The data obtained for the other labeled proteins were similarly calculated, and the values of $\mathrm{C}_{\mathrm{i}} / \mathrm{C}_{\mathrm{m}}$ at various time intervals between injection and delivery are presented in Figures 7 to 10 . The ordinates in Figures 6 to 10 are linear, and the ordinates in Figures 1 to 4 are logarithmic; the values of $C_{1}$

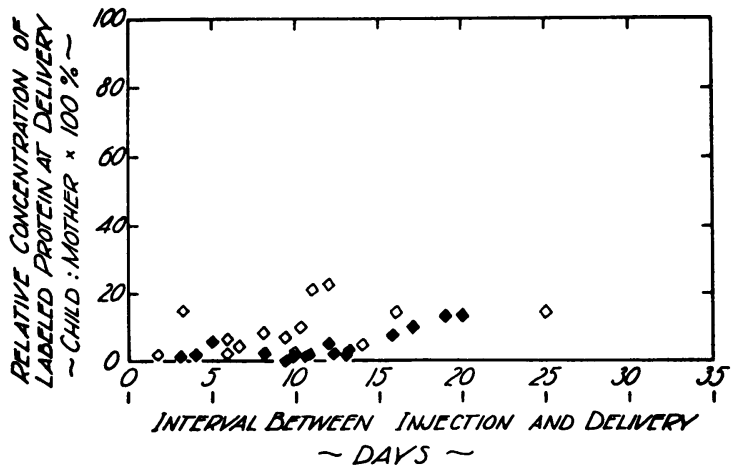

Fig. 7. Concentration of Radiolodinated acid gLyCOPROTEIN (HOLLOW DIAMONDS) AND TRANSFERRIN (SOLID DIAMONDS) IN CORD PLASMA OF THE INFANT AT BIRTH RELATIVE TO THE CONCENTRATIONS OF THESE PROTEINS IN THE MATERNaI. Plasma at DELivery. for a given protein can be obtained readily by multiplying the values of $\mathrm{C}_{\mathrm{i}} / \mathrm{C}_{\mathrm{m}}$ in Figures 7 to 10 by the values of $\mathrm{C}_{m} / \mathrm{C}_{\mathrm{o}}$ at a given time in Figures 3 and 4 . The rates at which the relative concentration of labeled acid glycoprotein (Figure 7), transferrin (Figure 7), fibrinogen (Figure 8), and $19 \mathrm{~S}$ macroglobulins (Figure 8) increased in fetal plasma were much lower than that found for labeled $7 \mathrm{~S} \gamma_{2}$-globulin; on the other hand, the relative concentration of labeled $F$ fragment increased more rapidly than did that of labeled $7 \mathrm{~S} \gamma_{2}$-globulin (Figure 9).

The relative concentration of $\mathrm{S}$ fragments in cord plasma increased as rapidly as did that of $F$ fragment for the first 12 hours after administration to the mother (Figure 10) ; unfortunately,

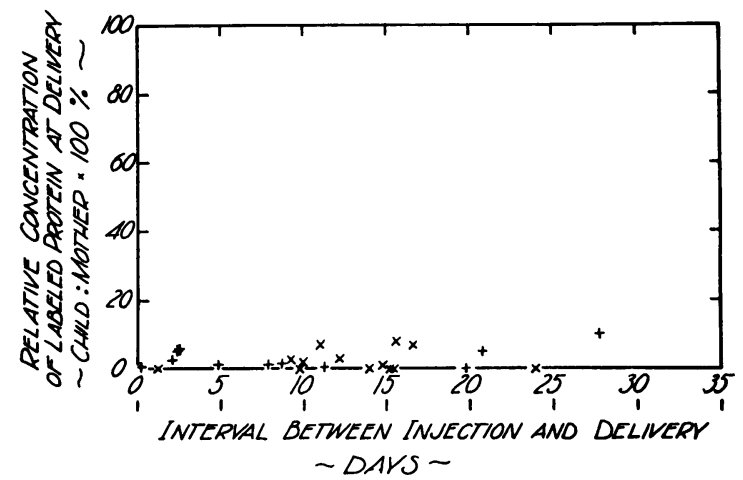

Fig. 8. Concentration of Radioiodinated $19 \mathrm{~S}$ macROGLOBULIN $(\times)$ AND FIBRINOGEN $(+)$ IN THE CORD PLASMA OF INFANTS AT BIRTH RELATIVE TO THAT IN THE MATERNAL PLASMA AT DELIVERY.

no observations were made during the period from 12 to 44 hours, and after this interval, little or no TCA-precipitable radioactivity could be detected in cord plasma. The only protein-bound radioactivity present in cord serum 12 hours after the injection of labeled $\mathrm{S}$ fragments into the mother migrated on starch as a $\gamma_{2}$-globulin, and upon passage through the mixed Sephadex columns, it was eluted after $7 \mathrm{~S} \gamma_{2}$-globulin but before albumin (Figure 5D). Over 95\% of this radioactivity was precipitable with rabbit antiserum. The largest fraction of the total radioactivity in cord serum at this time was included in Sephadex G-25 and G-50, and these fractions were not precipitable with TCA.

The relative concentration of labeled $\gamma_{\mathbf{u}}$-globulins in the infant increased as rapidly as that of 
F fragment during the 1-day period of observation (Figure 10), with the exception of one infant delivered at 25 hours; no observations of the relative concentration of $\gamma_{\mathrm{u}}$-globulins in cord plasma were made after 25 hours.

The cord plasma concentrations, $\mathrm{C}_{\mathrm{i}}$, of labeled $\mathrm{F}$ fragment were found to be from 25 to $75 \%$ of those of $7 \mathrm{~S} \gamma_{2}$-globulins during the period from approximately 1 day to 23 days after injection into the mother; 23 days was the longest interval of time between the injection of $\mathrm{F}$ fragment and delivery of the infant. The cord plasma concentrations of $\gamma_{\mathrm{u}}$-globulins and $\mathrm{S}$ fragments were very similar to each other, as indicated by the data in Figures 4 and 10, and these concentrations were approximately 10 to $25 \%$ of those for $\mathrm{F}$ fragment during the initial 12-hour period of observation of $\mathrm{S}$ fragments and the 1-day period of observation of the $\gamma_{\mathrm{u}}$-globulins.

III. The appearance of radioiodinated proteins in amniotic fluid. Of the four amniotic fluids obtained at the onset of delivery from women given labeled acid glycoprotein, the time intervals between injection and procurement of the fluids ranged from 3 days, 11 hours to 9 days, 11 hours. None of these fluids had detectable TCA-precipitable radioactivity; the concentration of labeled acid glycoprotein in the corresponding newborn plasma was 2.8 to $14.8 \%$ of that in the maternal plasma at delivery.

Amniotic fluid was secured at delivery from six women given labeled albumin; of these, four fluids were obtained from 3 to 9 hours after injection, and one fluid each was obtained after an interval of 25 days, 18 hours and 32 days, 14 hours, respectively. The latter two fluids had no detectable TCA-precipitable radioactivity, although the newborn plasma contained 14.2 and $15.2 \%$, respectively, of the amount present in the maternal plasma at that time. Protein-bound radioactivity was present in the early four fluids, however, the concentration being from 0.4 to $0.9 \%$ of that in the maternal plasma; the corresponding newborn plasma concentrations ranged from 1.4 to $2.7 \%$. The specific activity of the latter four amniotic fluids, or the counts per minute per milligram of endogenous albumin in a given sample, was approximately 3 to 5 times that in the infant's plasma.

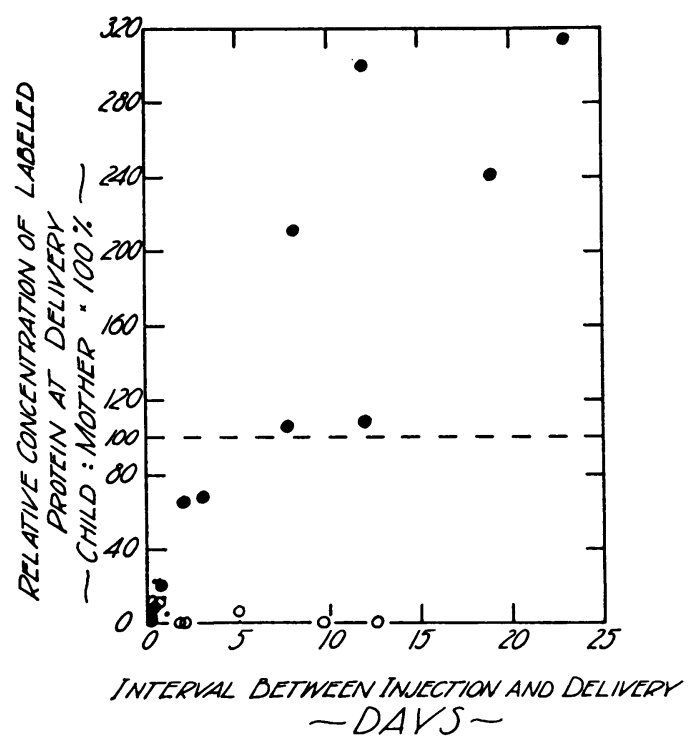

Fig. 9. Concentration of Radioiodinated F fragMENT (SOLID CIRCLES), S FRAGMENTS (HOLLOW CIRCLES), AND LOW MOLECULAR WEIGHT URINE $\boldsymbol{\gamma}$-GLOBULIN (DOTS) IN THE CORD PLASMA OF INFANTS AT BIRTH RELATIVE TO THE CONCENTRATIONS OF THESE PROTEINS IN THE MATERNAL PLASMA AT DELIVERY.

Of five amniotic fluids obtained at the delivery of mothers given labeled transferrin, the interval between injection and delivery ranged from 4 days to 19 days, 1 hour ; two fluids contained no detectable protein-bound radioactivity, and two con-

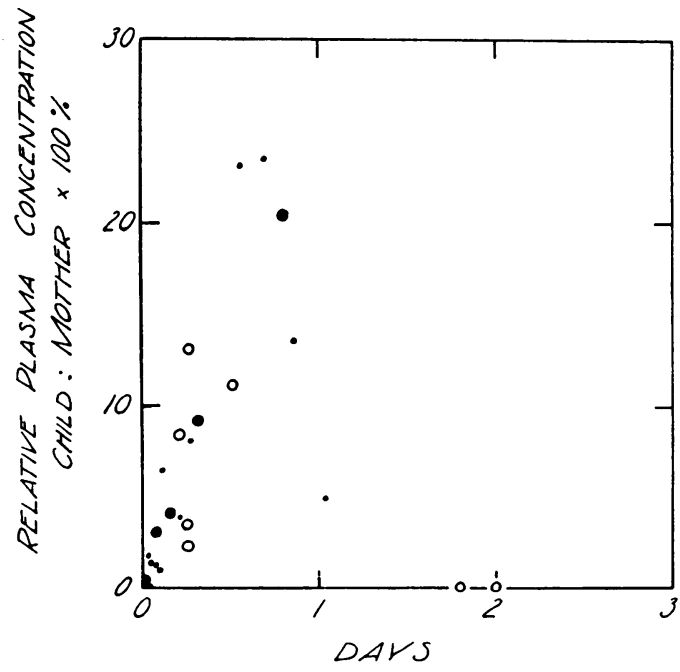

Fig. 10. Concentration of Radiolodinated F FragMENT, S FRAGMENTS, AND URINE $\gamma$-GLOBULIN (SYMBOLS AS IN Figure 9) in the CORD PLASMa OF infants at BIRTh RELATIVe to THE MATERNAL PLASMa CONCENTRATION OF THESE PROTEINS AT DELIVERY. This Figure is an expansion of the area about the origin of Figure 9. 
tained 0.1 and $0.4 \%$, respectively, of that in the maternal plasma.

Amniotic fluids were obtained from five women given labeled $7 \mathrm{~S} \gamma_{2}$-globulin. For four of these, the interval between injection and delivery was 4 hours. Two had no detectable protein-bound radioactivity, and two had only $0.1 \%$ of the radioactivity found in the maternal plasma; the infants at this time had 1.2 to $1.9 \%$ of the concentration of labeled $7 \mathrm{~S} \gamma_{2}$-globulin in the maternal plasma. Of the two infants corresponding to the two amniotic fluids that contained protein-bound radioactivity, the plasma concentration of labeled protein was 19 times that in the amniotic fluid, and the specific activity of the plasma $7 \mathrm{~S} \gamma_{2}$-globulin was approximately 2.5 times that in the amniotic fluid. The fluids obtained after an interval of 22 days, 22 hours had no detectable protein-bound radioactivity, whereas the concentration in the infant's plasma was $125 \%$ that of the mother.

Of the three amniotic fluids obtained at an interval of 4 hours to 8 days after the injection of labeled fibrinogen and of the three amniotic fluids obtained at an interval of 11 days to 16 days, 16 hours after the injection of $19 \mathrm{~S}$ macroglobulins, none had detectable protein-bound radioactivity.

\section{Discussion}

Brambell and his colleagues have presented extensive evidence in rodents to indicate that, in these animals, transfer of plasma proteins from mother to fetus is by way of the yolk sac splanchnopleur (11). They inferred from their findings that the pathway for maternofetal transfer of plasma proteins in primates might be the amniotic fluid. Wasz-Höckert, Wager, Hautala, and Widholm (31) indicated that amniotic fluid may not be the route of transfer of diphtheria antitoxin, a $7 \mathrm{~S} \gamma_{2}$ globulin antibody, in humans when they observed that infants with esophageal atresia had amounts of this antibody in their plasma similar to those in normal children. Bangham, Hobbs, and Terry (32) injected radioiodinated homologous serum into the amniotic fluid in pregnant rhesus monkeys and noted that little, if any, of the labeled protein was present in the fetal plasma 3 to 24 hours later; in the rhesus monkey, the route of transfer appeared to be transplacental. Dancis and his associates (33) injected radioiodinated albumin and $\gamma$-globulin into the circulation of women at 3 -month gestation who were to undergo therapeutic abortion 18 to 24 hours later and observed that the amount of TCA-precipitable radioactivity per unit volume of amniotic fluid was less than that present in fetal blood at the time of operation. To exclude a protein-concentrating mechanism by the fetus, they injected human serum containing tetanus antitoxin directly into the amniotic fluid in women near term who were to undergo Cesarean section and found that after 18 to 24 hours, the concentration of tetanus antitoxin in fetal blood was less than that in the amniotic fluid. In the study reported here, the specific activity of $7 \mathrm{~S}$ $\gamma_{2}$-globulin and transferrin in the amniotic fluid at delivery was always lower than that in the plasma of the infant, even when the protein had been given to the mother almost 3 weeks or more earlier; in several instances no labeled $7 \mathrm{~S} \gamma_{2}$-globulin or transferrin could be detected in amniotic fluid when the plasma of the newborn infant contained significant amounts of these proteins. Of the mothers given labeled acid glycoprotein, fibrinogen, or $19 \mathrm{~S}$ macroglobulins, those amniotic fluids that were examined did not contain detectable amounts of these proteins, although the proteins were present in the plasma of the corresponding infants. It would seem quite clear, therefore, that amniotic fluid is not the route of transfer in man for acid glycoprotein, transferrin, $7 \mathrm{~S} \gamma_{2}$-globulin, fibrinogen, or $19 \mathrm{~S}$ macroglobulin. That amniotic fluid is probably not the route of transfer for labeled albumin as well is indicated by the finding that two of the six amniotic fluids examined for this protein did not have detectable quantities, although significant amounts were present in the infant. The site of transfer of plasma proteins between mother and fetus in man appears to be the placenta.

In their study of the selective transfer of $7 \mathrm{~S}$ $\gamma_{2}$-globulin in pregnant rabbits, Brambell and his associates found that the serum concentration of Fragment III in the fetus 24 hours after placing the labeled fragments in the uterine lumen was 6 to 10 times that of Fragments I and II and only 25\% of that of labeled $7 \mathrm{~S} \gamma_{2}$-globulin (12). In the present study in pregnant women, the concentration of labeled $\mathrm{F}$ fragment, the analog of Fragment III, found in cord plasma, $C_{i}$, was 4 to 10 times that of labeled $S$ fragments, the analog of Frag- 
ments I and II, during the first 12 hours after administration to the mother, and varied from approximately 25 to $75 \%$ of the plasma concentration of $7 \mathrm{~S} \gamma_{2}$-globulin over the 23-day period of observation of the $\mathrm{F}$ fragment. Thus, the results presented here, despite the differences in species studied and the route of administration to the mother, are actually very similar to those obtained by Brambell. The $\gamma_{\mathrm{u}}$-globulins, which are immunochemically similar to $S$ fragments in that the two groups of proteins have similar antigenic determinants, possess antibody activity, and are immunochemically very different from $F$ fragments, had cord plasma concentrations similar to those of $S$ fragments.

On the basis of their data, Brambell and coworkers suggested that the selective maternofetal transfer of $7 \mathrm{~S} \gamma_{2}$-globulin was attributable to the nonantibody region of the molecule (12). However, the relative rate at which a labeled protein appears in fetal plasma is not a simple measure of the maternofetal transfer of the protein; the concentration of a given labeled protein in the plasma of the fetus is, of course, dependent upon 1) the rate of transfer from mother to fetus, which in turn is dependent upon the permeability of the placenta to that protein as well as the concentration of labeled protein in the maternal plasma, and 2) the rate of disappearance of the protein from the fetal circulation, which in turn is dependent upon the rate of degradation of the protein by the fetus, the net diffusion of labeled protein from the fetal plasma into the interstitial fluids of the fetus, and the net transfer of the protein from fetus to mother. Although two labeled proteins may cross the maternofetal barrier at the same rate, if the rates of degradation of the two proteins are different in either the fetus or in the mother, their plasma concentrations in the fetus at any given moment will be different. The serum concentration of labeled protein found in the rabbit fetus, when expressed only in terms of the amount placed in the uterine lumen 24 hours earlier, as in the study by Brambell and co-workers, is not necessarily a valid measure of the maternofetal transfer of that protein. Even if there were no differences in the rates of diffusion of the various labeled proteins from the uterine lumen and with the acceptance of Brambell's conclusion that transfer in the rabbit occurs primarily via the splanchnopleur so that the maternal concentration of the protein need not be involved, such data do not reflect any possible differences in the half-lives of different proteins in the fetus. In the present study, the half-life of $\mathrm{F}$ fragment in the pregnant women was more than 10 times longer than that of the major portion of the $\mathrm{S}$ fragments but only $20 \%$ of that of $7 \mathrm{~S} \gamma_{2}$-globulin. To take some account of these differences in half-life, the concentration of labeled protein in the cord plasma in this report was expressed in terms of the maternal plasma concentration present at the same time. Calculated in this manner, the relative concentration of $\mathrm{S}$ fragments in the fetus at term, at least during the first 12 hours of observation, was similar to that of $\gamma_{\mathrm{u}}$-globulins and of $\mathrm{F}$ fragment, and these concentrations were higher than those for $7 \mathrm{~S} \gamma_{2}$-globulin. To calculate the maternofetal transfer rates for these proteins, however, it is necessary to know the rates of degradation of the proteins in the fetus and their rates of transfer from the fetus to mother, and this information was not obtained in the present study nor in the study by Brambell and associates.

An explanation for the increase in $C_{i} / C_{m}$ for $\mathrm{S}$ fragments over the first 12 hours after injection and then the absence of $\mathrm{S}$ fragments in the fetus by 44 hours after injection would seem to lie in the metabolic heterogeneity of this polypeptide fraction. Approximately $90 \%$ of the preparation had a half-life of 0.3 days, whereas the remainder had a half-life of 4 days. A component with a half-life of 0.3 days would not readily be detected in the fetus 44 hours after injection, although the component with a 4-day half-life would be found in the maternal plasma. The evidence obtained by starch electrophoresis, Sephadex filtration, and immunochemical precipitation suggests that the protein-bound radioactivity present in cord plasma was a component of the $\mathrm{S}$ fragment preparation and not a degradation product: it migrated as a $\gamma_{2}$-globulin, but appeared in fractions different from $\gamma_{2}$-globulin when passed through Sephadex, and it reacted with specific antiserum. Although the protein-bound radioactivity present in maternal and cord plasma 12 hours after the injection differed considerably in electrophoretic and filtration characteristics from the bulk of the labeled protein present in the $\mathrm{S}$ fragment preparation before injection, this is compatible with the demonstrated 
metabolic heterogeneity of the $\mathrm{S}$ fragment preparation. Values obtained for $C_{i} / C_{m}$ at 44 hours after injection and later suggest that the fraction present in the fetus had a half-life shorter than 4 days or $C_{i} / C_{m}$ would not have decreased, since the fraction that remained in the maternal plasma had a half-life of 4 days. The values of $C_{i} / C_{m}$ also suggest that the component of 4-day half-life remaining in the maternal plasma did not pass from mother to fetus and that the $S$ fragment preparation was heterogeneous as regards transfer across the placenta.

The observation that different heterologous plasma proteins may reach different fetal serum concentrations after injection into the mother was noted by Brambell and co-workers (11) in rabbits. Bangham and associates (32) clearly pointed out that after injection of labeled homologous proteins in the rhesus monkey, the relative concentration of labeled albumin found in the fetus was less than that of labeled $\gamma$-globulin. This was found to be the case in the human fetus of 3 months gestation by Dancis and his associates (33) and in the human infant at term in this study. Apparently, each of the plasma proteins studied may pass from mother to fetus during the last month of gestation, although there may be considerable variation from individual to individual in the extent to which a given protein crosses the placenta, and in some instances, relatively little or no labeled $19 \mathrm{~S}$ macroglobulin, transferrin, fibrinogen, or even albumin appeared in the fetal plasma. The low relative plasma concentration of labeled $19 \mathrm{~S}$ macroglobulins found in the fetus at term, however, is in accord with the relative deficiency of this protein in the newborn (34). As stated earlier, however, relative fetal plasma concentrations of labeled proteins cannot be translated into transfer rates from mother to fetus until data are obtained concerning the rates of degradation of these proteins in the fetus and their rates of transfer from fetus to mother; such information was not obtained in this study nor in the earlier studies.

The relative fetal plasma concentration of labeled protein was determined as $C_{i} / C_{m}$. If any significant fraction of the labeled protein preparations used had been denatured so as to preclude maternofetal transfer, while such denatured protein remained in the circulation, $C_{i} / C_{m}$ would be lower than if the denatured component were not present and would equal $\mathrm{C}_{\mathrm{i}} /\left(\mathrm{C}_{\mathrm{m}}{ }^{\prime}+\mathrm{C}_{\mathrm{d}}\right)$, where $\mathrm{C}_{\mathrm{d}}$ represents the maternal plasma concentration of the denatured protein and $\mathrm{C}_{\mathrm{m}}{ }^{\prime}$ is the maternal plasma concentration of the protein that can pass to the fetus. Denaturation either during isolation of the unlabeled protein or during radioiodination results in rapid degradation of the labeled protein, usually with almost complete elimination of the protein within 24 to 48 hours (35), or results in a decrease in the half-life of the protein, or both (36). Thus, as the denatured protein is removed from the circulation, $\mathrm{C}_{\mathrm{i}} /\left(\mathrm{C}_{\mathrm{m}}{ }^{\prime}+\mathrm{C}_{\mathrm{d}}\right)$ approaches $C_{i} / C_{m}$, the same value as when no denatured nontransferable protein is present in the preparation. In any event, the average values of $\mathrm{C}_{\mathrm{i}} / \mathrm{C}_{\mathrm{m}}$ for all of the labeled proteins, with the exception of $\mathrm{S}$ fragments, increased gradually over the entire period of observation, whereas a sudden increase during the first 24 to 48 hours was not observed, suggesting that denaturation serious enough to result in rapid maternal degradation without maternofetal transfer was not a significant factor in the present study; the reasons for the decrease in $C_{i} / C_{m}$ for $S$ fragments after 12 hours were discussed earlier. In addition, the average half-life of the labeled $7 \mathrm{~S} \gamma_{2}$-globulin preparation in the pregnant women studied was 20.5 days, a value that agrees well with the average half-life of 23 days obtained by Cohen and Freeman (37) for radioiodinated $7 \mathrm{~S} \gamma_{2}$-globulin in normal adults, the protein in the latter study being isolated by DEAE cellulose column chromatography and radioiodinated by the iodine monochloride method (38). The half-life of transferrin in this study was 12 days, longer than that obtained for transferrin in normal adults by Katz, i.e., 6.7 to 8.4 days, who used a relatively simple $\mathrm{I}_{3}{ }^{-}$method of iodination (39). The half-life of 14.5 days obtained for the radioiodinated albumin preparation in these pregnant women is in accord with the half-life of this protein in normal adults reported by Berson, Yalow, Schreiber, and Post (40) who used a different method of iodination from that used here. Although such evidence is not proof that the labeled protein preparations in this study were not denatured, at least the preparations of albumin, transferrin, and $7 \mathrm{~S} \gamma_{2}$-globulin behaved as did simliar labeled preparations in which the proteins used were isolated or iodinated by meth- 
ods other than those used in this study. Since the $\mathrm{S}$ fragments and $\mathrm{F}$ fragments were obtained by enzymatic digestion of $7 \mathrm{~S} \gamma_{2}$-globulin, they are, of course, degradation products of the parent protein. The data in man and in animals would suggest that the method of iodination as used in this report would not significantly modify the half-lives of these proteins (41).

Although the transfer of $7 \mathrm{~S} \gamma_{2}$-globulin was observed for almost 35 days and the transfer of $F$ fragment was observed for 23 days, a steady state for labeled protein between mother and infant, at which time $C_{i} / C_{m}$ would become constant, was not reached. DuPan and his colleagues (42) similarly observed that radioiodinated $7 \mathrm{~S} \gamma_{2}$-globulin rapidly appears in the human fetus after injection of the protein into the mother and that the steady state is reached only slowly.

Since the amount of labeled protein that passes from mother to fetus was estimated in this study by measuring the protein-bound radioactivity in the cord plasma after delivery of the infant, it might be argued that the radioactivity found in the cord plasma was the consequence of a sudden transfer of whole blood from mother to fetus via the placenta during labor. Under these circumstances, the relative concentration of labeled protein in the infant's plasma at birth in per cent of that found in the maternal plasma at delivery would be at least $[\mathrm{T} /(\mathrm{P}+\mathrm{T})] 100 \%$, where $\mathrm{T}$ is the amount of plasma transfused into the infant and $\mathrm{P}$ is the plasma volume of the infant plus placenta. Therefore, to raise the child's plasma concentration only $1 \%$ would require an average transfusion of approximately $1.8 \mathrm{ml}$ of plasma or approximately $4.5 \mathrm{ml}$ of blood. Since the average concentration of each of the labeled proteins in the infant's plasma at some time after injection exceeded 5 to $10 \%$ of that in the maternal plasma at delivery, the average amount of blood transfused into the fetus at this point would have had to be approximately 22 to $44 \mathrm{ml}$ of blood. In the case of $\mathrm{F}$ fragment and $7 \mathrm{~S} \gamma_{2}$-globulin where the infant's concentration of labeled protein exceeded that in the maternal circulation, no amount of sudden transfusion of blood from mother to fetus could achieve this result. Thus, sudden transfusions from mother to infant during labor would not explain the data obtained.

The occurrence of concentrations of labeled proteins that are higher in the infant's plasma than in the maternal plasma is simply the consequence of tracer kinetics and does not indicate a higher concentration of specific endogenous protein (41). In infants whose mothers had been given labeled $7 \mathrm{~S} \gamma_{2}$-globulin, for example, the plasma concentration of labeled protein exceeded that in the mother 25 or more days after injection, but the concentration of endogenous $7 \mathrm{~S} \gamma_{2}$-globulin in the infant was equal to or slightly lower than that in the mother. The injected tracer protein behaves as do newly synthesized molecules of that specific protein entering the maternal vascular system.

\section{Summary}

Specific human plasma proteins were labeled with $\mathrm{I}^{131}$ and injected into pregnant women in the last month of gestation; the thyroids of both mother and fetus were effectively blocked to the uptake of radioiodide by prior and continuing administration of stable iodide. Protein-bound radioactivity in the plasma of the mother before and during delivery was determined as well as that present in the infant's plasma, and amniotic fluid when available, at birth. When possible, the protein-bound radioactivity in the infant's plasma was followed during the first few days of life. In this manner, 133 women and their respective infants were studied with one of the following proteins: acid glycoprotein, albumin, transferrin, $7 \mathrm{~S} \gamma_{2}$-globulin, fibrinogen, $19 \mathrm{~S}$ macroglobulin, $\mathrm{F}$ fragment from $7 \mathrm{~S} \gamma_{2}$-globulin, $\mathrm{S}$ fragments from $7 \mathrm{~S} \gamma_{2}$-globulin, and $1 \mathrm{~S}$ to $3 \mathrm{~S}$ urine $\gamma$-globulin ( $\gamma_{\mathbf{u}}$-globulin). The data indicate that: 1 ) All of the plasma proteins studied appeared in the fetus after administration to the mother but in different amounts. The plasma concentrations of labeled proteins in the fetus relative to those in the mother decreased in approximately the following order: $F$ fragment, a major fraction of $\mathrm{S}$ fragments and $\gamma_{\mathrm{u}}$-globulins, $7 \mathrm{~S} \gamma_{2}$-globulin, acid glycoprotein, albumin, transferrin, $19 \mathrm{~S}$ macroglobulin, and fibrinogen. In some instances, little or no labeled $19 \mathrm{~S}$ macroglobulin, transferrin, fibrinogen, or even albumin was present in the infant's plasma at birth. 2) The relative plasma concentrations of $\mathrm{F}$ fragment, or the nonantibody portion of the $7 \mathrm{~S} \gamma_{2}$-globulin molecule, a major fraction of the $S$ fragments, or those fragments 
of the $7 \mathrm{~S} \gamma_{2}$-globulin molecule that possess antibody activity, and the $\gamma_{\mathrm{u}}$-globulins, which are related immunochemically to the $\mathrm{S}$ fragments, were similar to each other, but they were higher than the relative plasma concentrations of $7 \mathrm{~S} \gamma_{2}$-globulin.

The problem of translating fetal plasma concentrations of labeled protein into maternofetal transfer rates in the absence of data concerning rates of degradation in the fetus and rates of transfer from fetus to mother is discussed.

\section{Acknowledgments}

We express our gratitude to Dr. Benjamin Eguiluz, Director of the Hospital de Gineco y Obstetricia, Centro Médico Nacional del I.M.S.S. and to Dr. Federico Gomez, formerly Director of the Hospital Infantil and now Director of the Hospital de Pediatria, Centro Médico Nacional del I.M.S.S., México, D. F., for their kindness, understanding, and encouragement in making possible our use of the facilities of those institutions for this study. We are also indebted to Dr. Fred Rosen of the Children's Hospital Medical Center, Boston, Dr. Pablo Yoshida of the Hospital Infantil de México, and Miss Mary Boesman of the Children's Hospital of Pittsburgh for their tireless assistance in various phases of this work.

\section{References}

1. Osborn, J. J., J. Dancis, and B. V. Rosenberg. Studies of the immunology of the newborn infant: III. Permeability of the placenta to maternal antibody during fetal life. Pediatrics 1952, 10, 450.

2. Vahlquist, B. Studies on diphtheria: I. The decrease of natural antitoxic immunity against diphtheria. Acta paediat. (Uppsala) 1948, 35, 117.

3. TenBroeck, C., and J. H. Bauer. The transmission of tetanus antitoxin through the placenta. Proc. Soc. exp. Biol. (N. Y.) 1923, 20, 399.

4. Timmerman, W. A. Zur Frage der Übertragung des Typhus " $\mathrm{H}$ " and "O"-Agglutinin von Mutter auf Kind. Z. Immun.-Forsch. 1931, 70, 388.

5. Perkins, F. T., R. Yetts, and W. Gaisford. Serological response of infants to poliomyelitis vaccine. Brit. med. J. 1958, 2, 68.

6. Kochwa, S., R. E. Rosenfield, L. Tallal, and L. R. Wasserman. Isoagglutinins associated with $\mathrm{ABO}$ erythroblastosis. J. clin. Invest. 1961, 40, 874.

7. Gitlin, D., F. S. Rosen, and J. G. Michael. Transient 19S gamma - -globulin deficiency in the newborn infant, and its significance. Pediatrics 1963, 31, 197.

8. Hitzig, W. H. Das Bluteiweissbild beim gesunden Säugling. Helv. paediat. Acta 1961, 16, 46.

9. Scheinberg, I. H., C. D. Cook, and J. A. Murphy. The concentration of copper and ceruloplasmin in maternal and infant plasma at delivery (abstract). J. clin. Invest. 1954, 33, 963.

10. Smithies, O. Zone electrophoresis in starch gels: group variations in the serum proteins of normal human adults. Biochem. J. 1955, 61, 629.

11. Brambell, F. W. R., W. A. Hemmings, and M. Henderson in Antibodies and Embryos. London, Athlone Press, 1951.

12. Brambell, F. W. R., W. A. Hemmings, C. L. Oakley, and R. R. Porter. The relative transmission of the fractions of papain hydrolyzed homologous $\gamma$-globulin from the uterine cavity to the foetal circulation in the rabbit. Proc. roy. Soc. B 1960, $151,478$.

13. Porter, R. R. The hydrolysis of rabbit $\gamma$-globulin and antibodies with crystalline papain. Biochem. J. 1959, 73, 119.

14. Smith, E. L., D. M. Brown, H. E. Weimer, and R. J. Winzler. Sedimentation, diffusion, and molecular weight of a mucoprotein from human plasma. J. biol. Chem. 1950, 185, 569.

15. Cohn, E. J., W. L. Hughes, Jr., and J. H. Weare. Preparation and properties of serum and plasma proteins. XIII. Crystallization of serum albumins from ethanol-water mixtures. J. Amer. chem. Soc. 1947, 69, 1753.

16. Gitlin, D., and C. A. Janeway. An immunochemical study of the albumins of serum, urine, ascitic fluid and edema fluid in the nephrotic syndrome. J. clin. Invest. 1952, 31, 223.

17. Koechlin, B. A. Preparation and properties of serum and plasma proteins. XXVIII. The $\beta_{1}$-metalcombining protein of human plasma. J. Amer. chem. Soc. 1952, 74, 2649.

18. Schultze, H. E., I. Göllner, K. Heide, M. Schönenberger, and G. Schwick. Zur Kenntnis der $\alpha$-Globuline des menschlichen Normalserums. J. Naturforsch. 1955, 10b, 463.

19. Blombäck, B., and M. Blombäck. Purification of human and bovine fibrinogen. Arkiv Kemi 1956, 10,415 .

20. Morrison, P. R., J. T. Edsall, and S. G. Miller. Preparation and properties of serum and plasma proteins. XVIII. The separation of purified fibrinogen from fraction I of human plasma. J. Amer. chem. Soc. 1948, 70, 3103.

21. Kunkel, H. G., J. H. Rockey, and T. Tomasi. Methods of separation and properties of antibodies of high molecular weight in Immunochemical Approaches to Problems in Microbiology, M. Heidelberger and O. J. Plescia, Eds. New Brunswick, N. J., Rutgers University Press, 1961, p. 30.

22. Hershgold, E. J., F. Cordoba, P. Charache, and D. Gitlin. A crystalline fragment from human gamma-globulin. Nature (Lond.) 1963, 199, 284.

23. McFarlane, A. S., and R. A. Kekwick. Physical properties of Bushy Stunt virus protein. Biochem. J. 1938, 32, 1607.

24. Edelman, G. M., J. F. Heremans, M.-Th. Heremans, and H. G. Kunkel. Immunological studies of hu- 
man $\gamma$-globulin. Relation of the precipitin lines of whole $\gamma$-globulin to those of the fragments produced by papain. J. exp. Med. 1960, 112, 203.

25. Merler, E., J. S. Remington, M. Finland, and D. Gitlin. Characterization of antibodies in normal human urine. J. clin. Invest. 1963, 42, 1340.

26. Pressman, D., and H. N. Eisen. The zone of localization of antibodies. V. An attempt to saturate antibody-binding sites in mouse kidney. J. Immunol. 1950, 64, 273.

27. Kunkel, H. G., and R. J. Slater. Zone electrophoresis in a starch supporting medium. Proc. Soc. exp. Biol. (N. Y.) 1952, 80, 42.

28. Porath, J., and P. Flodin. Gel filtration: a method for desalting and group separation. Nature (Lond.) 1959, 183, 1657.

29. Oudin, J., and P. Grabar. Etude quantitative du systéme précipitant ovalubumine-anticorps homologue de lapin. Ann. Inst. Pasteur 1944, 70, 7.

30. Janeway, C. A., and D. Gitlin. The gamma-globulins. Advanc. Pediat. 1957, 9, 65.

31. Wasz-Höckert, O., O. Wager, T. Hautala, and O. Widholm. Transmission of antibodies from mother to fetus. A study of the diphtheria antitoxin level in the newborn with oesophageal atresia. Ann. Med. exp. Fenn. 1956, 34, 444.

32. Bangham, D. R., K. R. Hobbs, and R. J. Terry. Selective placental transfer of serum-proteins in the rhesus. Lancet 1958, 2, 351.
33. Dancis, J., J. Lind, M. Uratz, J. Simolens, and P. Vara. Placental transfer of proteins in human gestation. Amer. J. Obstet. Gynec. 1961, 82, 167.

34. Hitzig, W. H. Die physiologische Entwicklung der "Immunglobuline" (gamma- und beta ${ }_{2}-$ Globuline). Helv. paediat. Acta 1957, 12, 596.

35. Margen, S., and H. Tarver. Comparative studies on the turnover of serum albumin in normal human subjects. J. clin. Invest. 1956, 35, 1161.

36. McFarlane, A. S. Labeling of pasma proteins with radioactive iodine. Biochem. J. 1956, 62, 135.

37. Cohen, S., and T. Freeman. Metabolic heterogeneity of human $\gamma$-globulin. Biochem. J. 1960, 76, 475.

38. McFarlane, A. S. Efficient trace-labeling of proteins with iodine. Nature (Lond.) 1958, 182, 53.

39. Katz, J. H. Iron and protein kinetics studied by means of doubly labeled human crystalline transferrin. J. clin. Invest. 1961, 40, 2143.

40. Berson, S. A., R. S. Yalow, S. S. Schreiber, and J. Post. Tracer experiments with $\mathrm{I}^{131}$ labeled human serum albumin: Distribution and degradation studies. J. clin. Invest. 1953, 32, 746.

41. Gitlin, D., and C. A. Janeway. Some isotopic studies on the distribution and metabolism of plasma proteins. Advanc. biol. med. Phys. 1960, 7, 249.

42. DuPan, R. M., P. Wenger, S. Koechli, J.-J. Scheidegger, and J. Roux. Etude du passage de la $\gamma$-globuline marquée à travers le placenta humain. Clin. chim. Acta 1959, 4, 110. 